Giuseppe Mari*

Mediolan

\title{
Chrześcijaństwo a humanizm. Szanse i wyzwania w zsekularyzowanej kulturze
}

Moją główną intencją w niniejszym artykule ${ }^{1}$ jest ukazanie związku zachodzącego między wiarą chrześcijańską a myśleniem humanistycznym. W związku z tym formułuję tezę, że chrześcijaństwa nie należy redukować do humanizmu. Takie uszczuplenie prowadzi bowiem nieuchronnie do zsekularyzowania niezwykłego przesłania wiary chrześcijańskiej. Wydaje mi się, że obecny kryzys wiary jest następstwem błędu popełnionego w tym właśnie zakresie. W kolejnych punktach nakreślę zależność między chrześcijaństwem a humanizmem, następnie wskażę na novum, jakie wnosi chrześcijaństwo w myśl humanistyczną, czyli postrzeganie człowieka jako osoby, wreszcie spróbuję pokazać, jakie znaczenie dla humanizmu ma jego teocentryczny wymiar.

* Prof. dr Giuseppe Mari jest profesorem w Catholic University of the Sacred Heart of Milan. Adres: Università Cattolica del Sacro Cuore, Facoltà di Scienze della Formazione, Largo A. Gemelli, 1 - 20123 Milano; e-mail: giuseppe.mari@unicatt.it.

1 Ten sam tekst ukazał się w języku angielskim: „Christian education as humanistic education? Opportunity and challenge within the secularized culture", Forum Pedagogiczne 2 (2017): 267-277. 


\section{Wiara chrześcijańska a uznanie godności człowieka}

Nie ma wątpliwości co do tego, że już starożytni filozofowie greccy dostrzegali w człowieku specyficzną godność ${ }^{2}$. Potwierdzeniem tego może być początkowy fragment Arystotelesowskiej Polityki, w którym Stagiryta zastanawia się nad różnicą zachodzącą między językiem zwierząt a językiem ludzkim. Pisze on między innymi:

Głos jest oznaką radości i bólu, dlatego posiadają go i inne istoty (rozwój ich posunął się bowiem tak daleko, że mają zdolność odczuwania bólu i radości, tudzież wyrażania tego między sobą). Ale mowa służy do określania tego, co pożyteczne czy szkodliwe, jak również i tego, co sprawiedliwe czy też niesprawiedliwe.

To bowiem jest właściwością człowieka, odróżniającą go od innych stworzeń żyjących, że on jedyny ma zdolność rozróżniania dobra i zła, sprawiedliwości i niesprawiedliwości i tym podobnych ${ }^{3}$.

Podobne refleksje snuje nauczyciel Arystotelesa, Platon. W mało znanym dialogu Kratylos wyjaśnia pochodzenie słowa anthropos w następujący sposób:

Nazwa ánthropos bowiem znaczy, że w przeciwieństwie do innych zwierząt, które widzą, lecz nie obserwują ani nie porównują, ani nie rozpatrują, ánthrōpos zaś, czyli człowiek, skoro coś dostrzegł, to znaczy ópōpe, to zarówno anathrề (rozpatruje), jak i wnioskuje, czyli logídzetai, z tego, co zobaczył. Słusznie więc jako jedyny ze zwierząt człowiek został nazwany ánthrōpos, jako anathrōn hà ópōpe (rozpatrujący to, co zobaczył).

Czy można na podstawie powyższych stwierdzeń uważać, że w antycznej kulturze greckiej powszechnie znano i uznawano godność człowieka? Niestety nie. Ta sama bowiem cywilizacja grecka, która okazała się tak wrażliwa na wyjątkowość istoty ludzkiej (do tego stopnia, że w nawiązaniu

2 Werner Jaeger, Paideia: The Ideals of Greek Culture, vol. 1-3 (Oxford: Oxford University Press, 1986).

3 Arystoteles, „Polityka”, w: Dzieła wszystkie, t. 6 (Warszawa: Wydawnictwo Naukowe PWN, 2001), [1253] 27.

${ }^{4}$ Platon, Kratylos (Wrocław: Zakład Narodowy im. Ossolińskich, 1990), [399c] 18. 
do wszechogarniającej harmonii, którą wyrażał termin kósmos, opatrywano człowieka mianem mikrókosmos, czyli świat w miniaturze), ta właśnie cywilizacja traktowała niewolnictwo jako coś zgodnego z naturą. Świadczy o tym następujący fragment Ekonomiki Arystotelesa: „Pierwszą i najpotrzebniejszą własnością jest ta, która jest najlepsza i najprzydatniejsza, a jest nią człowiek. Dlatego trzeba przede wszystkim zaopatrzyć się w dobrych niewolników"s. Jak przystało na zapobiegliwego gospodarza, Stagiryta zwraca uwagę, że pan powinien być sprawiedliwy. Wyjaśnia zaś to następująco: „Stosunek do niewolników tak się powinno ułożyć, by im na zuchwalstwa nie pozwalać, ale też ich nie drażnić; tym, których się do poważniejszych zadań używa, i szacunku nie skąpić, a ciężko pracującym zapewnić obfite pożywienie". W Polityce omawiany autor opatruje niewolnika mianem własności pana i żywego narzędzia. Twierdzi on między innymi:

Własność jest tedy częścią domu, a nauka o zdobywaniu własności częścią nauki o gospodarstwie domowym (bez rzeczy koniecznych nie można żyć, a tym samym i żyć wygodnie).

Jak do określonych kunsztów niezbędnie są potrzebne właściwe narzędzia, jeśli dzieło ma być odpowiednio wykończone, tak i do gospodarstwa domowego. $\mathrm{Z}$ narzędzi jedne są martwe, drugie żywe, tak np. dla sternika ster jest narzędziem martwym, jego zaś zastępca narzędziem żywym; pomocnik bowiem stanowi rodzaj narzędzia przy wykonywaniu pracy. Odpowiednio do tego także i w gospodarstwie domowym rzeczy, jakie się posiada, są narzędziem do życia, mienie jest sumą takich narzędzi, a niewolnik żywą własnością7.

Nam współczesnym powyższy sposób myślenia wydaje się nie do przyjęcia, a nawet okropieństwem, jednak nie można zapominać, że starożytni nieco inaczej patrzyli na kwestię niewolnictwa. W społeczeństwie greckim, czy później rzymskim, było ono ściśle znormalizowaną instytucją ${ }^{8}$. Niewolnikiem mógł stać się ktoś z powodu niezapłaconych długów, za popełnienie przestępstwa lub jako jeniec wojenny. Z czasem bezlitosne czy okrutne obchodzenie się z niewolnikami zostało prawnie zakazane. Najsłynniejszym

5 Arystoteles, „Ekonomika”, w: Dzieła wszystkie, t. 6 (Warszawa: Wydawnictwo Naukowe PWN, 2001), [1344] 235.

6 Tamże.

7 Arystoteles, „Polityka”, [1253] 29.

${ }^{8}$ Nick R. E. Fisher, Slavery in Classic Greece (London: Bristol Classical, 1998); Keith Bradley, Slavery and Society at Rome (Cambridge: Cambridge University Press, 2013). 
starożytnym orędownikiem ulżenia doli niewolników był Lucius Annaeus Seneka. W jednym z listów zwraca się do Lucyliusza, właściciela niewolników, w następujących słowach: ,Jest [on - dop. G.M.] niewolnikiem”, ale zaraz dodaje: „Lecz może człowiekiem wolnego ducha. «Jest niewolnikiem». Czy może mu to szkodzić? Pokaż, kto nim nie jest"9. Jednak nie należy zapominać, że również Seneka miał niewolników. A zatem nikt - przynajmniej w obrębie cywilizacji starożytnej - nie doszedł do tej konkluzji, że trzeba zrezygnować z niewolnictwa. Rozpatrywano je raczej jako sprawę ekonomiczną i polityczną, a nie z punktu widzenia moralnego czy antropologicznego. Dopiero dzięki chrześcijaństwu sytuacja ta kompletnie się zmieniła.

W świetle nauki Chrystusa człowiek jest jedynym stworzeniem powstałym na obraz i podobieństwo samego Boga (Rdz 1, 26). Z tego powodu chrześcijanie podkreślają różnicę jakościową między istotą ludzką a zwierzętami. W Psalmie 8 mówi się o tym następująco:

O Panie, nasz Boże,

jak przedziwne Twe imię po wszystkiej ziemi!

Tyś swój majestat wyniósł nad niebiosa.

Sprawiłeś, że [nawet] usta dzieci i niemowląt oddają Ci chwałę,

na przekór Twym przeciwnikom,

aby poskromić nieprzyjaciela i wroga.

Gdy patrzę na Twe niebo, dzieło Twych palców,

księżyc i gwiazdy, któreś Ty utwierdził:

czym jest człowiek, że o nim pamiętasz,

i czym - syn człowieczy, że się nim zajmujesz?

Uczyniłeś go niewiele mniejszym od istot niebieskich, chwałą i czcią go uwieńczyłeś.

Obdarzyłeś go władzą nad dziełami rąk Twoich:

owce i bydło wszelakie,

a nadto i polne stada,

ptactwo powietrzne oraz ryby morskie,

wszystko, co szlaki mórz przemierza.

O Panie, nasz Panie,

jak przedziwne jest Twe imię po wszystkiej ziemi!

9 Seneka, Listy moralne do Lucyliusza (Warszawa: Wydawnictwo PWN, 1961), 157. 
Moglibyśmy skonfrontować treść powyższego psalmu ze słynnym chórem z Antygony Sofoklesa:

Siła jest dziwów, lecz nad wszystkie sięga

Dziwy człowieka potęga.

Bo on prze śmiało poza sine morze,

Gdy toń się wzdyma i kłębi,

I z roku na rok swym lemieszem porze

Matkę ziemicę do głębi.

Lotny ród ptaków i stepu zwierzęta,

I dzieci fali usidla on w pęta,

Wszystko rozumem zwycięży.

Dzikiego zwierza z gór ściągnie na błonie,

Krnąbrny kark tura i grzywiaste konie

Ujarzmi w swojej uprzęży.

Wynalazł mowę i myśli dał skrzydła,

I życie ujął w porządku prawidła,

Od mroźnych wichrów na deszcze i gromy

Zbudował sobie schroniska i domy,

$\mathrm{Na}$ wszystko z radą on gotów.

Lecz choćby śmiało patrzał w wiek daleki,

Choć ma na bóle i cierpienia leki,

Śmierci nie ujdzie on grotów ${ }^{10}$.

Na czym polega różnica między zaprezentowanymi powyżej dwoma podejściami? Psalm biblijny jest pełen podziwu dla człowieka jako stworzenia Bożego, podczas gdy tekst greckiej tragedii wychwala istotę ludzką, okazując wobec niej zarazem podziw i lęk. Ten nieco zaskakujący splot ambiwalentnych uczuć wyraża użyte przez Sofoklesa słowo deinós. Znaczy ono zarówno „wspaniały”, jak i „straszny”. Ponadto w swoim dramacie Sofokles traktuje człowieka tak, jakby ukształtował się sam. Zgodnie z tym ujęciem tożsamość ludzka zależna jest wyłącznie od natury i patrząc $\mathrm{z}$ tego punktu widzenia, nie ma żadnej różnicy między człowiekiem a istotami pozaludzkimi. Inaczej jest natomiast w Biblii. Tutaj tożsamość człowieka pochodzi wprost od Boga.

${ }^{10}$ Sofokles, Antygona (Warszawa: Pruszyński i S-ka, 2004), 160-161. 
Jedną z najradykalniejszych kontestacji greckiego i rzymskiego stanowiska antropologicznego można odnaleźć u Grzegorza z Nyssy. Szczególnie ostro skrytykował on doktrynę mikrokosmosu ${ }^{11}$. W szesnastym rozdziale swojego dzieła pt. O stworzeniu człowieka pisze na ten temat następująco:

Powróćmy do słów Bożych: „Uczyńmy człowieka na nasz obraz i podobieństwo". Jak małe i niegodne ludzkiej wzniosłości były wyobrażenia niektórych filozofów, którzy wynosili człowieka do, jak sądzili, [godności] tego świata. Mówili bowiem, że człowiek jest mikrokosmosem, złożonym z tych samych pierwiastków, co wszechświat. Pragnąc dzięki temu zaszczytnemu imieniu wywyższyć naturę ludzką, zapomnieli, że tym sposobem ozdabiają człowieka przymiotami właściwymi komarowi i myszy. Rzeczywiście są one złożone z czterech pierwiastków, ponieważ wszystko, co żyje, składa się z nich w różnych proporcjach. Czym zatem wyróżniałby się człowiek, jeślibyśmy uznali go za obraz i podobieństwo świata: otaczającego [wszystko] nieba, zmiennej ziemi, wszystkiego, co w nich się zawiera i porusza się razem z nimi?

$\mathrm{Na}$ czym zatem, według nauki Kościoła, polega wielkość człowieka? Nie na podobieństwie do stworzonego świata, lecz na tym, że człowiek stanowi obraz natury Stwórcy ${ }^{12}$.

Jak wyjaśnić wskazany powyżej zwrotny punkt w historii cywilizacji zachodniej? Jego źródłem stała się nowa antropologia, wyrastająca z wiary chrześcijańskiej i ucieleśniona $\mathrm{w}$ zreinterpretowanym łacińskim terminie persona, który odpowiada greckiemu słowu prósopon ${ }^{13}$.

\section{Pojęcie „osoba” jako źródło i rdzeń chrześcijańskiej rewolucji antropologicznej}

Jak wspomniałem poprzednio, Biblia uznaje, że zarówno mężczyzna, jak i kobieta są obrazem Boga. Z przyjęcia tego aksjomatu wynika szczególna relacja między stworzeniem, którym jest człowiek, a jego Stwórcą. Relacja ta jest tak silna, że zbawienie przedstawiane jest w Biblii jako

${ }^{11}$ Etienne Gilson, Historia filozofii chrześcijańskiej w wiekach średnich (Warszawa: Pax, 1966), 56-59.

12 Grzegorz z Nyssy, O stworzeniu człowieka (Kraków: Wydawnictwo WAM, 2006), 91.

13 Josef Pieper, The Christian Idea of Man (South Bend ID: St. Augustine's Press, 2011); Michele Saracino, Christian Anthropology (Mahwah, NJ: Paulist Press, 2015). 
odkupienie grzechów mężczyzny i kobiety, a nie zbuntowanych aniołów (por. Hbr 2, 16)! Ponadto należy z naciskiem podkreślić, że w Jezusie Chrystusie Bóg pokochał bezwarunkowo każdego człowieka bezgraniczną miłością. Pisze o tym święty Paweł w Liście do Rzymian następująco:

Któż nas może odłączyć od miłości Chrystusowej? Utrapienie, ucisk czy prześladowanie, głód czy nagość, niebezpieczeństwo czy miecz? Jak to jest napisane: „Z powodu Ciebie zabijają nas przez cały dzień, uważają nas za owce przeznaczone na rzeź". Ale we wszystkim tym odnosimy pełne zwycięstwo dzięki Temu, który nas umiłował. I jestem pewien, że ani śmierć, ani życie, ani aniołowie, ani Zwierzchności, ani rzeczy teraźniejsze, ani przyszłe, ani Moce, ani co wysokie, ani co głębokie, ani jakiekolwiek inne stworzenie nie zdoła nas odłączyć od miłości Boga, która jest w Chrystusie Jezusie, Panu naszym (Rz 8, $35-39)$.

O tym, o czym wspomniałem nieco wcześniej, najpełniej mówi się w $L i$ ście do Filemona. Jest on adresowany do chrześcijanina o imieniu Filemon, właściciela niewolnika (posiadanie niewolników było w starożytności tak bardzo społecznie akceptowane, że początkowo chrześcijanie niczym nie odróżniali się pod tym względem od innych). Będąc w więzieniu, Paweł poznał niewolnika Filemona, a ten pod wpływem nauczania Apostoła narodów ochrzcił się. Teraz Paweł odsyła go Filemonowi ze słowami:

Jego ci odsyłam; ty zaś jego, to jest serce moje, przyjmij do domu! Zamierzałem go trzymać przy sobie, aby zamiast ciebie oddawał mi usługi w kajdanach [noszonych dla] Ewangelii. Jednakże postanowiłem nie uczynić niczego bez twojej zgody, aby dobry twój czyn był nie jakby z musu, ale z dobrej woli. Może bowiem po to oddalił się od ciebie na krótki czas, abyś go odebrał na zawsze, już nie jako niewolnika, lecz więcej niż niewolnika, jako brata umiłowanego. [Takim jest on] zwłaszcza dla mnie, ileż więcej dla ciebie zarówno w doczesności, jak w Panu (Flm 1, 12-16).

Wiara chrześcijańska nie działa zatem jak rewolucja zewnętrzna w stylu buntu Spartakusa, który wydarzył się o jedno stulecie wcześniej, lecz od wewnątrz, albo lepiej: w głębi człowieka, przemieniając jego życie duchowe. U szczytu epoki nowożytnej Monteskiusz jako wiarygodny świadek, bo niemogący być posądzonym przez nikogo o sprzyjanie Kościołowi, przyznaje otwarcie, że chrześcijaństwo jako pierwsze odrzuciło niewolnictwo, mimo że sami chrześcijanie przez jakiś czas byli jeszcze zaangażowani w jego 
praktykę ${ }^{14}$. Z tego właśnie powodu papież Jan Paweł II w Roku Jubileuszowym 2000 ogłosił Dzień Przebaczenia. W homilii wygłoszonej podczas Eucharystii sprawowanej w dniu 12 marca 2000 roku w Bazylice Watykańskiej powiedział on między innymi:

Kiedy chwalimy Boga, który w swojej miłosiernej miłości wzbudził w Kościele wspaniałe żniwo świętości, zapału misyjnego, całkowicie bezinteresownej służby Chrystusowi i bliźniemu, nie możemy zarazem nie uznać różnych form niewierności Ewangelii, jakiej dopuścili się niektórzy nasi bracia, zwłaszcza w drugim tysiącleciu. Prosimy o przebaczenie za podziały, jakie nastąpiły wśród chrześcijan, za przemoc, jaką niektórzy z nich stosowali w służbie prawdy, oraz za postawy nieufności i wrogości, przyjmowane nieraz wobec wyznawców innych religii ${ }^{15}$.

Co jest sercem nowej chrześcijańskiej antropologii? Niewątpliwie jest nim idea osoby. Z kulturowego punktu widzenia idea ta jest najbardziej rewolucyjną koncepcją chrześcijaństwa. Co prawda słowo persona nie było obce cywilizacji starożytnej, jednak używano go w zupełnie innym znaczeniu. W kulturze łacińskiej termin persona oznaczał coś zewnętrznego i powierzchownego, tak jak maska noszona przez aktorów w teatrze (po grecku prósopon) lub status prawny (warto przypomnieć, że w nomenklaturze prawniczej nadal posługujemy się wyrażeniem „osoba prawna”). Pod wpływem wiary chrześcijańskiej „osoba” zaczęła oznaczać człowieka jako podmiot obdarzony specyficzną i właściwą jemu tylko godnością. Termin ten odwołuje się do wewnętrznej tożsamości człowieka, a nie zewnętrznej, obejmując jego głębię zarówno psychiczną, jak i duchową. Wyjątkowy charakter osoby znakomicie wyraził Ryszard od św. Wiktora. W Traktacie o Trójcy Świętej pisze on między innymi:

Nie mamy dostępnych słów, aby dać przykład indywidualnej substancjalności; jednak, aby zwiększyć wyrazistość mowy, możemy odnieść się do nazwy własnej. I tak od Daniela możemy utworzyć „,danielskość”, jak od człowieka „człowieczeństwo”. „Danielskość” można zatem interpretować jako substancjalność lub lepiej, jako byt, który sprawia, że Daniel jest tą substancją, którą

${ }^{14}$ Monteskiusz, O duchu praw (Warszawa: Hachette, 2009), 297.

15 Jan Paweł II, Przebaczamy i prosimy o przebaczenie. Homilia Ojca Świętego wygłoszona w Bazylice św. Piotra 12 III 2000, http://www.fjp2.com/pl/jan-pawel-ii/biblioteka-online/ homilie/2266-day-for-pardon (dostęp: 5.07.2017). 
jest i której żadna inna [substancja] nie może z nim dzielić. Zatem podczas gdy człowieczeństwo lub cielesność są wspólne dla wielu, „danielskość” jest absolutnie nieprzekazywalna, w tym sensie, że przynależy do niego w taki sposób, że nie może należeć do nikogo innego ${ }^{16}$.

Każdy mężczyzna i każda kobieta są zatem niepowtarzalni i wyjątkowi. Na tej podstawie św. Tomasz z Akwinu wyjaśnia etymologię słowa persona następująco: „to jakby: sama przez się jedna - per se una” (STh I, q. 29, a. 4) ${ }^{17}$.

Jak narodziło się to nowe znaczenie? Było ono konsekwencją ewangelizacji chrześcijańskiej. Starożytni teologowie chrześcijańscy używali bowiem słowa „osoba” na określenie chrześcijańskiego Boga jako nieodłącznej komunii Ojca i Syna, i Ducha Świętego - trzech współistotnych Osób Trójcy Świętej. A zatem słowo to odnosiło się do samego sedna tożsamości Boga jako bytu strukturalnie relacyjnego. Ze względu zaś na biblijne nauczanie o człowieku jako imago Dei tym samym słowem zaczęto określać tożsamość człowieka jako jedność relacyjną.

Jak wynika z zacytowanego powyżej Psalmu 8 , pierwsza i podstawowa relacja człowieka to ta odnosząca go do Boga-Stwórcy. Patrząc przez pryzmat myślenia starożytnego, człowiek jest wobec Boga tym samym, co niewolnik wobec pana. Jednak w świetle chrześcijańskiego objawienia człowiek, stając przed Bogiem, spotyka nie despotycznego hegemona, lecz Ojca miłującego go ponad wszystko. I to właśnie jest clou chrześcijańskiej ewangelizacji, czyli euagghélion jako Dobrej Nowiny. Święty Paweł w Liście do Rzymian pisze:

Albowiem wszyscy ci, których prowadzi Duch Boży, są synami Bożymi. Nie otrzymaliście przecież ducha niewoli, by się znowu pogrążyć w bojaźni, ale otrzymaliście ducha przybrania za synów, w którym możemy wołać: „Abba, Ojcze!" Sam Duch wspiera swym świadectwem naszego ducha, że jesteśmy dziećmi Bożymi. Jeżeli zaś jesteśmy dziećmi, to i dziedzicami: dziedzicami Boga, a współdziedzicami Chrystusa, skoro wspólnie z Nim cierpimy po to, by też wspólnie mieć udział w chwale (Rz 8, 14-17).

${ }^{16}$ Ryszard od św. Wiktora, „Traktat o Trójcy Świętej”, Studia Antyczne i Mediewistyczne 5 (2007): 146.

17 Tomasz z Akwinu, Suma Teologiczna, t. 25: Bóg-Człowiek Syn Maryi (London: „Veritas", 1964), 25. 
Bycie osobą oznacza zatem w pierwszym rzędzie uznanie za dziecko Boga. Stąd pochodzi nowa tożsamość człowieka. Apostoł Narodów w Liście do Efezjan i w Liście do Kolosan mówi o niej jako o „nowym człowieku” (Ef 2, 15; 4, 22-24; Kol 3, 9-11). Zwrot ten oznacza radykalną zmianę statusu antropologicznego, spowodowaną wyłącznie miłością Boga, który ze swojej istoty ,jest miłością" (1 J 4, 8. 16). Jak już wspomniałem, świadkiem tego jest święty Paweł, który miłości Boga doświadczył bezpośrednio. Również papież Franciszek nieustannie powołuje się na Miłosierdzie Boga ${ }^{18}$. W ten sposób kroczy on drogą wyznaczoną przez swojego świętego poprzednika - Jana Pawła II ${ }^{19}$, który w kalendarzu liturgicznym Kościoła katolickiego ustanowił pierwszą niedzielę po Uroczystości Zmartwychwstania Chrystusa Świętem Miłosierdzia Bożego i który pisał o istocie chrześcijańskiego orędzia tak: „Człowiek jest kochany przez Boga! Oto proste, a jakże przejmujące Orędzie, które Kościół jest winien człowiekowi. Każdy chrześcijanin może i musi słowem oraz życiem głosić: Bóg cię kocha, Chrystus przyszedł dla ciebie, Chrystus dla ciebie jest «Drogą, i Prawdą i Życiem!» (J 14, 6)"20.

Oczywiste jest, że wiara chrześcijańska stawia człowieka w centrum stworzenia. Musimy jednak pamiętać, że antropocentryzm chrześcijański nie jest absolutny, lecz względny i że jest on konsekwencją teocentryzmu. Jest to subtelna, ale jakże ważna różnica, której grozi dzisiaj niezrozumienie lub, co gorsza, zapomnienie ${ }^{21}$.

\section{Konsekwencje uznania humanizmu bez wymiaru teocentrycznego}

Pierwotnym źródłem ruchu praw człowieka jest antropocentryzm chrześcijański. Jest on również niezbędnym punktem odniesienia dla współczesnych społeczeństw europejskich, ponieważ wobec złożonej sytuacji politycznej, społecznej i etycznej pozwala rozpoznać ich wspólną podstawę. Nieprzypadkowo jednak prawa człowieka zostały skodyfikowane dopiero w ciągu ostatnich stuleci, w epoce nowożytnej. Właściwe zrozumienie tego

18 Francis, The Church of Mercy (London: Darton, Longman \& Todd, 2014).

19 John B. Bransfield, The Human Person according to John Paul II (Boston: Pauline, 2010).

${ }^{20}$ Jan Paweł II, Posynodalna Adhortacja Apostolska Christifideles Laici, 34, http://www. opoka.org.pl/biblioteka/W/WP/jan_pawel_ii/adhortacje/christifideles.html (dostęp: 5.07.2017).

${ }^{21}$ John P. Bequette, Christian Humanism (Lanham: University Press of America, 2004). 
faktu wyjaśnia, dlaczego nie powinniśmy zapominać jako chrześcijanie, że ta sama nowożytność, która ogłosiła prawa człowieka, jest zarazem punktem wyjścia dla sekularyzacji jako ruchu zmierzającego do przekształcenia wiary chrześcijańskiej w „wiarę" całkowicie immanentną i świecką, to znaczy niewykraczającą poza ramy określone przez myślenie zlaicyzowane. Jednym z wielu przykładów może być tutaj przekształcenie wiary w Opatrzność w ,wiarę w postęp". Nie jest bynajmniej przypadkiem, że papież Franciszek zdecydowanie krytykuje ,światowość” wewnątrz Kościoła.

Trzeba jasno sobie uzmysłowić konsekwencje współczesnej sekularyzacji nie tylko w odniesieniu do wiary chrześcijańskiej, lecz również wspólnoty kulturowej, jaką współtworzą chrześcijanie. Dopóki zachodni antropocentryzm opierał się na chrześcijańskim Objawieniu, dopóty nie był on autoreferencyjny. Sekularyzacja przyniosła natomiast odrzucenie odwołania do Boga, co zrodziło prometejskie podejście do stworzenia. Właśnie dlatego w ramach relacji między człowiekiem a światem przyrody pojawiła się tendencja do wykorzystywania zasobów naturalnych bez ograniczeń. Znakomicie pisze o tym papież Franciszek w encyklice Laudato Si ${ }^{\prime}$ :

W naszych czasach nastąpił znaczny przerost antropocentryzmu, który w nowym przebraniu nadal zagraża wszelkiemu odniesieniu się do czegoś wspólnego i wszelkim próbom wzmocnienia więzi społecznych. $Z$ tego względu nadeszła pora, aby znów zwracać uwagę na rzeczywistość z ograniczeniami, jakie ona narzuca, które z kolei stanowią możliwości bardziej zdrowego i owocnego rozwoju ludzkiego i społecznego. Nieodpowiednia prezentacja antropologii chrześcijańskiej doprowadziła do promocji błędnego przekonania na temat relacji człowieka ze światem. Wiele razy przedstawiano prometejskie marzenie panowania nad światem, które wywołało wrażenie, że troska o naturę jest sprawą ludzi słabych. Tymczasem prawidłową interpretacją pojęcia człowieka jako „pana” wszechświata jest rozumienie go w sensie „odpowiedzialnego zarządcy" $(116)^{22}$.

Współczesna nieodpowiedzialność ekologiczna jest w istocie związana z odrzuceniem władzy Boga nad stworzeniem. „Rewolucja chrześcijańska” zrodziła pełny humanizm, uznając godność człowieka wynikającą z osobistej i nieusuwalnej miłości Boga do każdego człowieka. Sekularyzacja zachowała antropocentryzm, ale zmieniła go radykalnie przez autoreferencyjność, do jakiej rości sobie prawo człowiek niepodlegający już władzy Boga.

${ }^{22}$ Franciszek, Laudato Si'. W trosce o wspólny dom (Kraków: Wydawnictwo M). 
Dlatego mamy dziś do czynienia z posthumanistycznymi tendencjami spowodowanymi kryzysem ekologicznym. Jestem zdania, że opowiadając się za humanizmem, należy tendencje te odrzucić. Obecny kryzys wiary wymaga bowiem rozpoznania tego, co jest jej istotą. Humanizm stanowi oczywiście jej część, ale błędem jest sprowadzanie chrześcijaństwa do humanizmu, ponieważ ten ostatni - przynajmniej w epoce nowożytnej - stał się świecką ideą, która przestała odwoływać się do wiary chrześcijańskiej tak, jak to było w pierwszym etapie rozwoju ideałów humanistycznych (np. Francesco Petrarka, Guarino Veronese, Vittorino da Feltre itp.).

W miarę rozprzestrzenienia się sekularyzacji coraz wyraźniejsza stawała się zmiana w postawie człowieka wobec wiedzy i działania w świecie. Ideał nauki przekształcał się w coraz bardziej utylitarną wiedzę, a ludzki sposób działania w coraz bardziej funkcjonalny. O tej przemianie świadczą wymownie słowa Francisa Bacona: „Wiedza i potęga ludzka to jedno i to samo"23. Tak oto narodziła się nowa koncepcja prawdy podporządkowanej pragmatyzmowi i utylitaryzmowi. A w konsekwencji tego problematyczną stała się jej relacja $\mathrm{z}$ wiarą. W sceptycyzm rozpowszechniony w nauce wplątuje się dodatkowo szerszy kryzys prawdy. W encyklice Lumen Fidei papież Franciszek pisze o tym wyraźnie:

Przypominanie o więzi wiary z prawdą jest dziś bardziej niż kiedykolwiek potrzebne, właśnie z powodu kryzysu prawdy, jaki przeżywamy. We współczesnej kulturze często występuje tendencja do przyjmowania za jedyną prawdę tę związaną z techniką: prawdziwe jest to, co człowiek potrafi zbudować i zmierzyć dzięki swojej wiedzy; jest to prawdziwe, bo funkcjonuje, a tym samym czyni życie wygodniejszym i łatwiejszym. Dzisiaj wydaje się to jedyną prawdą pewną, jedyną, którą można podzielić się z innymi, jedyną, o której można dyskutować i wspólnie się w nią zaangażować $(25)^{24}$.

Ktoś mógłby zapytać: co jest nie tak z identyfikacją prawdy i techniczną funkcjonalnością? Otóż to, że powodują one bezużyteczność ludzkiego życia, a przecież istota ludzka jest wartością samą w sobie, co - jak wykazano powyżej - zawiera się już w słowie „osoba”. Dlatego obecny kryzys wiary, związany z kryzysem prawdy, jest także kryzysem antropologicznym. Z tego punktu widzenia należy przypomnieć właściwą relację między humanizmem

${ }^{23}$ Franciszek Bacon, Novum organum (Warszawa: Państwowe Wydawnictwo Naukowe, 1955), 55.

${ }^{24}$ Franciszek, Lumen Fidei (Kraków: Wydawnictwo św. Stanisława BM). 
a chrześcijaństwem. To ostatnie nie jest wyłącznie ani przede wszystkim antropocentryczne, lecz w swojej istocie teocentryczne. Jezus Chrystus jest bowiem „drogą i prawdą, i życiem” (J 14, 6), „Alfą i Omegą, Początkiem i Końcem" (Ap 21, 6). Na początku Biblii jest Bóg, który stwarza wszechświat; na końcu zaś Jezus Chrystus, który zapowiada swój powrót. Cała narracja chrześcijańska wychodzi od Boga i wraca do Boga. On właśnie jest jedynym źródłem teocentryzmu chrześcijańskiego.

Przez ostatnie stulecia sekularyzacja spowodowała, że wiara przestała być postrzegana jako niezbędny element ludzkiego życia. Dlatego dzisiejsza kultura bardzo przypomina starożytną cywilizację pogańską, przykładowo w sprawie legitymizacji samobójstwa. Cywilizacja pogańska - przynajmniej w pierwszym okresie - była sceptyczna i materialistyczna. Co zrobili w tej sytuacji pierwsi teologowie chrześcijańscy? Wykazywali wiarygodność wiary jako takiej. Przeczytajmy, co pisze na ten temat Arnobiusz Starszy:

Ponieważ macie zwyczaj wyśmiewać naszą wiarę i żartujecie sobie, drwiąc z naszej gotowości uwierzenia, powiedzcie nam: o sympatyczni, wymalowani i nasyceni napojem czystej mądrości, czy jest w życiu jakaś działalność, jakieś ważne zajęcie, które nie zaczynałoby się, nie byłoby podejmowane, rozpoczynane przez ludzi bez uprzedniej wiary? Podróżujecie i pływacie: i nie wierzycie, iż powrócicie do domu, gdy wypełnicie wasze sprawy? Spulchniacie ziemię za pomocą pługa i wrzucacie w nią ziarna wszelkiej jakości: i nie wierzycie, że zbierzecie plony wraz ze zmianą pór roku? Zawieracie związki małżeńskie: i nie wierzycie, iż pozostaną czyste i że układ będzie służył obojgu małżonkom? Macie dzieci: i nie ufacie, że będą posiadały dobre zdrowie i stopniowo dożyją wieku starczego? Chorzy, powierzacie się lekarzom, czy nie wierzycie, że choroby po usunięciu niebezpieczeństwa mogą być złagodzone? Walczycie z nieprzyjaciółmi i nie wierzycie w odniesienie [ostatecznego] sukcesu po serii zwycięskich potyczek? Czcicie i uwielbiacie bogów: i nie wierzycie, że istnieją i z uwagą nastawiają uszu na wasze modlitwy?25

Nie zapominajmy, że dla Platona wiara (pistis) jest najniższym poziomem poznania. W Państwie dzieli on poznanie na poziomy - ,jedno (króluje) nad rodzajem przedmiotów myślowych i w świecie myśli, a drugie w świecie widzialnym" 26 . Słowo pistis dotyczy jego zdaniem poznania zmy-

${ }_{25}$ Arnobiusz, Adversus Nationes Libri VII, II, 8, http://www.thelatinlibrary.com/arnobius/ arnobius2.shtml (dostęp: 23.09.2017).

26 Platon, Państwo (Warszawa: Wydawnictwo AKME, 1990), [509] 353. 
słowego, ponieważ odnosi się do rzeczy materialnych, które są tylko pozorne. Natomiast prawdziwa rzeczywistość jest ideą duchową ${ }^{27}$.

Współcześnie mamy do czynienia z czymś bardzo podobnym. Mówi się bowiem, że wiara nie jest prawdziwym poznaniem, ponieważ nie może dać żadnej pewności w opisie lub że dotyczy wyłącznie tego, co jest prawdziwe $\mathrm{z}$ osobistego (subiektywnego/własnego/prywatnego) punktu widzenia. Tymczasem wiadomo, że najbardziej zaawansowana epistemologia nie traktuje o weryfikowalności, lecz o falsyfikowalności jako podstawowym kryterium nauki. Przykładowo warto zastanowić się, jak Karl Popper definiuje poznanie naukowe. Dana teoria jest naukowa nie dlatego, że potwierdza ją doświadczenie, lecz dlatego, że można będzie ją obalić w przyszłości za pomocą innych doświadczeń. Tym samym Popper odrzucił pozytywistyczną koncepcję, zgodnie z którą wiedza naukowa jest ostateczna. Wychodząc od zmiennej rzeczywistości, wprowadził on ewolucjonistyczną koncepcję nauki. Według Poppera prawa naukowe nie są nienaruszalnymi ideami, lecz tymczasowymi konstruktami. Atrybut naukowości przysługuje im tylko dlatego, że mogą być powtórnie przemyślane przez innych naukowców i zmodyfikowane. W Logice odkrycia naukowego pisze on: „Otóż moim zdaniem teorie naukowe nigdy nie dają się uzasadnić lub zweryfikować w pełni, są jednakże sprawdzalne. Powiem zatem, że obiektywizm twierdzeń naukowych tkwi w fakcie, że podlegają one sprawdzeniu intersubiektywnemu"28.

W świetle tych zmian znamiennie brzmią słowa papieża Benedykt XVI, który w encyklice Caritas in Veritate stwierdził: „Rozszerzenie naszej koncepcji rozumu i posługiwania się nim jest nieodzowne, aby odpowiednio wyważyć wszystkie pojęcia związane z kwestią rozwoju i rozwiązania problemów społeczno-ekonomicznych" (31) ${ }^{29}$. Uwaga ta odnosi się również do zagadnień filozoficznych i kulturowych. W tym samym rozdziale, ale nieco wcześniej, napisał on: „Zbytnia wycinkowość wiedzy, zamykanie się nauk humanistycznych na metafizykę, trudność w dialogu nauk z teologią szkodzą nie tylko rozwojowi wiedzy, ale także rozwojowi narodów, ponieważ w takich przypadkach trudniej jest dostrzec całe dobro człowieka w różnych wymiarach, jakie je charakteryzują" ${ }^{30}$.

27 Tamże, [509-511] 353-355.

${ }^{28}$ Karl Popper, Logika odkrycia naukowego (Warszawa: Wydawnictwo Naukowe PWN, 2002), 42.

${ }^{29}$ Benedykt XVI, Caritas in Veritate (Poznań: Księgarnia św. Wojciecha).

${ }^{30}$ Tamże. 


\section{Wnioski}

Co wynika $\mathrm{z}$ tego dla wychowania chrześcijańskiego? Przede wszystkim to, że wiara chrześcijańska jest wia rą, a zatem nie tylko czymś odnoszącym się do egzystencjalnego spotkania z Jezusem, lecz również rodzajem poznania i to niesytuującym się najniżej, jak chciał tego Platon, lecz najwyżej. Wobec obecnej tendencji neopozytywistycznej wyzwaniem dla wychowania chrześcijańskiego jest zademonstrowanie, że wiara jest niezbędna do poznania świata i postępowania będącego jego następstwem. Skoro bowiem człowiek, z racji swojej godności, został obdarzony przez Stwórcę wolnością, jego cechą charakterystyczną jest bycie otwartym na przyszłość. Wiara stanowi przecież wiedzę najbardziej przystającą do przyszłości. Z tego powodu jest ona sprzymierzeńcem, a nie rywalem ludzkiej wolności.

Wychodząc od uznania wiary za rodzaj poznania, a nie jedynie doświadczenia egzystencjalnego, i za niezbędny element tożsamości człowieka, można ponownie przemyśleć relację wiary z humanizmem. Jak stwierdziłem powyżej, zachodzi genetyczny związek między tymi dwoma zjawiskami. Jednak ponieważ w epoce nowożytnej nastąpiło zsekularyzowanie humanizmu, ograniczenie wychowania chrześcijańskiego do humanizmu grozi jego całkowitym zlaicyzowaniem, które polega na przekształceniu w bliżej nieokreśloną filantropię. Papież Franciszek zwrócił uwagę na to zagrożenie w homilii wygłoszonej 14 marca 2013 roku podczas pierwszej Mszy świętej sprawowanej po swoim wyborze przed kardynałami. Wówczas powiedział: „Możemy wędrować, ile chcemy, możemy budować wiele rzeczy, ale jeśli nie wyznajemy Jezusa Chrystusa, nie dzieje się dobrze. Staniemy się użyteczną organizacją pozarządową, ale nie Kościołem, Oblubienicą Chrystusa" ${ }^{\text {31 }}$.

To samo dzieje się w wychowaniu chrześcijańskim. Jeśli będziemy je praktykować wyłącznie lub głównie jako wychowanie humanistyczne, przestanie być wychowaniem chrześcijańskim, lecz nie dlatego, że humanizm jest wrogiem chrześcijaństwa, lecz dlatego, że to wiara chrześcijańska dała mu życie, a nie przeciwnie. Tylko wtedy, gdy jasne będzie, że bycie chrześcijaninem oznacza dostrzeganie - przez Łaskę - czegoś oryginalnego i szczególnego w człowieczeństwie drugiego człowieka, wówczas prowadzi to do pełnego humanizmu. Oczywiście, mówiąc o wierze jako poznaniu, nie odnoszę się do

${ }^{31}$ Franciszek, Homilia Ojca Świętego Franciszka, 14.03.2013, https://w2.vatican.va/ content/francesco/pl/homilies/2013/documents/papa-francesco_20130314_omelia-cardinali. html (dostęp: 6.07.2017). 
gnostycyzmu, ponieważ chrześcijańska idea wiary jest związana z Łaską, która jest darem. Ludzka istota rozumna może zaakceptować i współpracować z tym darem lub go odrzucić, ponieważ - jak pisze święty Tomasz z Akwinu: „Łaska nie niszczy natury, ale ją udoskonala” (STh I, q. 1, a. 8, ad 2). I jeżeli wyjdziemy od tej pewności, to wówczas również wychowanie chrześcijańskie przechowa prymat wiary, chroniąc ją przed sekularyzacją, i będzie wychowywaniem do pełnego humanizmu.

Ttum. Jacek Rosa, korekta: Dariusz Stękowski

\section{Christianity and Humanism. Opportunity and Challenge within the Secularized Culture (Summary)}

There is a strong and original relationship between Christian faith and Humanism, but it is necessary not to reduce the Christian education to Humanism. In fact, it was the Christian faith which gave birth to Humanism, not vice versa. It is necessary to put the distinction in order to avoid the reduction of the Christian education to the generic philanthropy. The Christian faith is, first of all, an encounter with Jesus, not only from the existential point of view, but also as a peculiar knowledge through Christ as God's Word.

Keywords: Christianity; humanism; evangelization.

\section{Chrześcijaństwo a humanizm. Szanse i wyzwania w zsekularyzowanej kulturze (Streszczenie)}

Relacja między wiarą chrześcijańską a humanizmem jest silna i oryginalna, ale można ją dostrzec tylko wówczas, gdy przesłania chrześcijańskiego nie zawęża się do humanizmu. Przesłanie to bowiem wytworzyło humanizm, a nie odwrotnie. Aby uniknąć redukcji wiary do filantropii ogólnie pojmowanej, konieczne jest nie tylko dostrzeżenie wskazanego rozróżnienia, lecz również zrozumienie jego wielorakich konsekwencji. Wiara chrześcijańska w swojej istocie jest przede wszystkim spotkaniem z Jezusem Chrystusem i to nie tylko z egzystencjalnego punktu widzenia, lecz również jako szczególny rodzaj wiedzy zapośredniczonej przez osobowy kontakt z Nim jako Słowem Boga. $Z$ tego powodu jest ona sprzymierzeńcem, a nie rywalem ludzkiej wolności.

Słowa kluczowe: chrześcijaństwo; humanizm; ewangelizacja. 


\section{Bibliografia}

Arnobiusz. Adversus Nationes Libri VII. http://www.thelatinlibrary.com/arnobius/ arnobius2.shtml (dostęp: 23.09.2017).

Arystoteles. „Ekonomika”. W: Dzieła wszystkie, t. 6, 232-263. Warszawa: Wydawnictwo Naukowe PWN, 2001.

Arystoteles. „Polityka”. W: Dzieła wszystkie, t. 6, 25-226. Warszawa: Wydawnictwo Naukowe PWN, 2001.

Bacon, Franciszek. Novum organum. Warszawa: Państwowe Wydawnictwo Naukowe, 1955.

Benedykt XVI. Caritas in Veritate. Poznań: Księgarnia św. Wojciecha.

Bequette, John P. Christian Humanism. Lanham: University Press of America, 2004.

Bradley, Keith. Slavery and Society at Rome. Cambridge: Cambridge University Press, 2013.

Bransfield, John B. The Human Person according to John Paul II. Boston: Pauline, 2010.

Fisher, Nick R.E. Slavery in Classic Greece. London: Bristol Classical, 1998.

Francis. The Church of Mercy. London: Darton, Longman \& Todd, 2014.

Franciszek. Homilia Ojca Świętego Franciszka, 14.03.2013. https://w2.vatican.va/ content/francesco/pl/homilies/2013/documents/papa-francesco_20130314_ omelia-cardinali.html (dostęp: 6.07.2017).

Franciszek. Laudato Si'. W trosce o wspólny dom. Kraków: Wydawnictwo M.

Franciszek. Lumen Fidei. Kraków: Wydawnictwo św. Stanisława BM.

Gilson, Etienne. Historia filozofii chrześcijańskiej w wiekach średnich. Warszawa: Pax, 1966.

Grzegorz z Nyssy. O stworzeniu człowieka. Kraków: Wydawnictwo WAM, 2006.

Jaeger, Werner. Paideia: The Ideals of Greek Culture, vol. 1-3. Oxford: Oxford University Press, 1986.

Jan Paweł II. Posynodalna Adhortacja Apostolska Christifideles Laici. http://www. opoka.org.pl/biblioteka/W/WP/jan_pawel_ii/adhortacje/christifideles.html (dostęp: 5.07.2017).

Jan Paweł II. Przebaczamy i prosimy o przebaczenie. Homilia Ojca Świętego wygłoszona w Bazylice św. Piotra 12 III 2000. http://www.fjp2.com/pl/jan-pawel-ii/ biblioteka-online/homilie/2266-day-for-pardon (dostęp: 5.07.2017).

Monteskiusz. O duchu praw. Warszawa: Hachette, 2009.

Pieper, Josef. The Christian Idea of Man. South Bend ID: St. Augustine's Press, 2011.

Platon. Kratylos. Wrocław: Zakład Narodowy im. Ossolińskich, 1990. 
Platon. Państwo. Warszawa: Wydawnictwo AKME, 1990.

Popper, Karl. Logika odkrycia naukowego. Warszawa: Wydawnictwo Naukowe PWN, 2002.

Ryszard od św. Wiktora. „Traktat o Trójcy Świętej”. Studia Antyczne i Mediewistyczne 5 (2007): 144-146.

Saracino, Michele. Christian Anthropology. Mahwah, NJ: Paulist Press, 2015.

Seneka. Listy moralne do Lucyliusza. Warszawa: Wydawnictwo PWN, 1961.

Sofokles. Antygona. Warszawa: Pruszyński i S-ka, 2004.

Tomasz z Akwinu. Suma teologiczna, t. 25: Bóg-Człowiek Syn Maryi. London: „Veritas", 1964. 